\title{
Reproductive biology of Periopthalmus barbarus (Linneaus 1766 ) in new Calabar River, Nigeria
}

\author{
K.O.Chukwu, S.N.Deekae and U.U.Gabriel \\ Department of Fisheries and Aquatic Environment, Rivers State University of Science and \\ Technology, Port-Harcourt Rivers State, Nigeria. \\ ABSTRACT
}

\begin{abstract}
Periophthalmus barbarus $(\mathrm{n}=600)$ sampled over a twelve month period (February 2008 January 2009) in New Calabar River Nigeria was analyzed for their breeding activities. The length at which $50 \%$ of the samples matured was $10.2 \mathrm{~cm}$ for females and $10.8 \mathrm{~cm}$ for males. Absolute fecundity was $860-13852$ with a mean of $4400.25 \pm 545.34$. A relative fecundity of $90.53 / \mathrm{cm}$ to $1154.16 / \mathrm{cm}$ with a mean of $421 \pm 45.87$ was also observed. The annual sex ratio was 1:1.4 (female: male). The seasonal sex ratio showed male dominance in the wet season but even in dry season. Spawning occurred all year round, with peak from February to July. Hepatosomatic index (mean values $1.24 \pm 0.061$ and $1.38 \pm 0.089$ for females and males respectively) and gonadosomatic index (mean values $1.72 \pm 0.142$ and $0.23 \pm 0.027$ for females and males respectively) presented monthly variations which suggested changing feeding and reproductive activities.
\end{abstract}

Keywords: Reproductive, Biology, Mudskippers, Periophthalmus, Breeding.

\section{INTRODUCTION}

Reproduction in mudskippers follows a rather elaborate courtship routine and nuptial parade in which the male leads the female to his burrow where mating occurs (Brillet, 1970). (Mcgregory, 1999) reported that the eggs are deposited on the wall of the burrow by the female with the male in attendance. However according to another observer details of the completion of hatching and early development are not known and have to date only received preliminary attention in the laboratory

Studies by Etim et. al., (2002) on Periphthalmus barbarus in Imo estuary revealed that the males spawn once in a year from February to May and the female from March to may. The size at which $50 \%$ of the specimen matured

was $10.2 \mathrm{~cm}$ (total length) for females and $10.5 \mathrm{~cm}$ for males. The median size at spawning was $10.8 \mathrm{~cm}$ for females and $11.9 \mathrm{~cm}$ for males the restriction in spawning duration becomes appreciable when compared to Pellonula leomensis which was reported to spawn all year round by Ezenwaji and Offiah (2003). The purpose of this study is to further provide information on the breeding activities of the species in the natural environment.

\section{MATERIALS AND METHODS}

The study was carried out in New Calabar River. The river lies within $4^{0} 15^{1} \mathrm{~N}$ and $4^{0} 45^{1} \mathrm{~N}$ and $6^{0} 57^{1}$ and
$7^{0} 04^{1} E$.The sampling was done at Eagle cement region of the river.

Samples were collected biweekly for each month from February 2008 to January 2009. The fish was caught using traps made from bamboo. They were $30 \mathrm{~cm}$ long and had a diameter of $5 \mathrm{~cm}$. The traps were buried in the mud flat at low tide with smashed Uca tangeri (West African Fiddler Crab) Sprinkled around it to attract the mudskippers. Three traps were used and positioned about 30 meters apart, and left for about one hour. Samples were pooled together and preserved in 10\% formaldehyde solution. Measurements were carried out for total length (TL) using a measuring board to the nearest $0.01 \mathrm{~cm}$. Weights of samples were measured by a top loading weighing balance to the nearest $0.01 \mathrm{~g}$.

Gonads were studied microscopically to determine stage of gonad development. Four stages were identified.

$\begin{array}{lll}\text { i } & - & \text { Immature } \\ \text { ii } & - & \text { maturing } \\ \text { iii } & - & \text { mature } \\ \text { iv } & - & \text { Spent. }\end{array}$

Size at maturity was determined as the length at which $50 \%$ of individuals were in gonad stage III (Ezenwaji and Offiah. 2003).

Fecundity, is defined as the number of spawnable Oocytes in both ovaries. (Ezenwaji and Offiah. 2003) 
The relationship between Fecundity and gonad weight, and total weight, was determined by linear regression, Relative Fecundity was calculated by counting the number of Ocytes per miligram of females total body weight. The values of total fecundity were regressed against total length, total weight and gonad weight to verify how they are related.

(Adebisi 1987, Vinicus et.al. 2004, Inyang and Ezewaji 2004).

The gonadosomatic index (GSI) was determined as $\mathrm{GSI}=\mathrm{W} 1 / \mathrm{W} 2 \times 100$

When W1 - gonad weight (g)' W2 - fish weight (g) less gonad weight, likewise the hepatosomatic index was calculated as $\mathrm{HSI}=\mathrm{W} 1 / \mathrm{W} 2 \times 100$ where $\mathrm{W} 1$ is liver weight, W2 is fish weight less liver weight (Vinicius el. al., 2004, Ezewaji and Offiah 2003).

The ratio of the sexes were determined annually, seasonally and its departure from $1: 1$ by $X^{2}$ ( Chi square test)

The annual mean GSI and HSI for both sexes where tested for variation by $\mathrm{t}$ test. The annual mean absolute and relative fecundities where also tested for variation by $t$ test. The following variables where tested for correlation GSI vs HSI for both sexes, GSI vs rainfall for both sexes, HSI vs rainfall for both sexes.

\section{RESULTS}

Results of length-weight measurements $(n=600)$ gave the following ranges, $4.1 \mathrm{~cm}-14.2 \mathrm{~cm}$, and $0.70 \mathrm{~g}$ $39.62 \mathrm{~g}$. The mean length of samples was

$8.64 \pm 1.27 \mathrm{~cm}$ and the mean weight was $11.16 \pm 7.29 \mathrm{~g}$

The length at which $50 \%$ of the samples matured for females was $10.2 \mathrm{~cm}$ and $10.8 \mathrm{~cm}$ for males. The absolute fecundity ranged from 860 to 13852 , with an annual mean of $4400.25 \pm 545.34$. The relative fecundity ranged from $90.53 / \mathrm{cm}$ to $1154.16 / \mathrm{cm}$, with an annual mea of $421.08 \pm 45.87$, the monthly values are given on (Table 1).The absolute and relative fecundities were not significantly different between dry and wet seasons at $(P>0.05)$.

The annual mean sex ratio was 1:1.4 for (female: male). This varied from 1:4 in April to 1:1 in October. The annual sex ratio gave a significant deviation from the 1:1 $\left(X^{2}=6.86\right.$, df $\left.=1, P<0.01\right)$. The seasonal sex ratio showed male dominance in the wet season $1: 1.83, \quad\left(X^{2}=12.9, \quad d f=1, \quad P<0.01\right)$ but an even distribution of the sexes in the dry season 1:0.94 $\left(X^{2}\right.$ $=0.095, \mathrm{df}=1, \mathrm{P}<0.05)$ not significantly differrent.

Spawning occurred all year round but with peak between February and July. Although most matured samples used for this study after the peak breeding season were spent, there were few gravid females and unspent males.

The relationship of fecundity and other measured parameters were regressed for the function, $Y=a+b$ ${ }^{*} X$, where $Y$ is fecundity.

Gonad weight fecundity, $Y=-0.9789+12469.7^{*} X$, where $X$ is Gonadweight and $r=1.00$

Length fecundity, $Y=-3143.72+737.233^{\star} X$, where $X$ is Bodylength and

$r=0.4640$.

Liver fecundity, $Y=2548.62+8798.20^{*} \mathrm{X}$, where $\mathrm{X}$ is Liverweight and

$r=0.3730$.

Bodyweight fecundity, $Y=285.399+297.392^{*} X$, where is Bodyweight and $r=0.5620$

Table 1: Mean Monthly absolute and Relative fecundity for Periophthalmus barbarus

\begin{tabular}{|l|c|c|}
\hline Month & $\begin{array}{c}\text { Absolute } \\
\text { Fecundity }\end{array}$ & $\begin{array}{c}\text { Relative } \\
\text { Fecundit } \\
\text { y/cm }\end{array}$ \\
\hline February & $4728.25 \pm 3316.53$ & $427.54 \pm 262.46$ \\
\hline March & $4330.79 \pm 2500.20$ & $400.51 \pm 211.64$ \\
\hline April & $3933.33 \pm 1683.86$ & $373.47 \pm 160.81$ \\
\hline May & $3271.60 \pm 2779.72$ & $399.31 \pm 303.84$ \\
\hline June & $7446.50 \pm 5360.65$ & $667.00 \pm 458.78$ \\
\hline July & $2144.00 \pm 00$ & $199.52 \pm 00$ \\
\hline August & $2375.00 \pm 572.76$ & $250.66 \pm 48.08$ \\
\hline September & $8977.00 \pm 00$ & $787.46 \pm 00$ \\
\hline October & $3631.00 \pm 1784.59$ & $314.44 \pm 137.71$ \\
\hline November & $4438.5 \pm 934.09$ & $479.63 \pm 112.53$ \\
\hline December & $3316 \pm 422.85$ & $314.16 \pm 16.97$ \\
\hline January & $4214.00 \pm 00$ & $444.48 \pm 00$ \\
\hline Dry & $4109.76 \pm 216.76$ & $173.48 \pm 61.31$ \\
\hline Wet & $\underline{4691.24 \pm 1160.49}$ & $\underline{255.77 \pm 108.87}$ \\
\hline
\end{tabular}

Months with sd 00 recorded only one gravid sample.

Gonadosomatic index (GSI): The mean monthly gonadosomatic index for females was high from February to June, $(2.44 \pm 0.37$ for February was the maximum value) but recorded a fall between July and January $(0.56 \pm 0.14$ for July was minimum). While for males high figures were observed between February and April $(0.39 \pm 0.14$ for February was at the peak), November and December also recorded high figures but figures recorded between May and October were low $(0.10 \pm 0.002$ for October was the least) except September which showed some increase.

Hepatosomatic index (HSI): The hepatosomatic index for females was even throughout the year with occasional falls for a few months. The mean values ranged from $1.57 \pm 0.16$ in February to $0.93 \pm 0.23$ in 
January. While for males, the highest mean value of $1.93 \pm 0.25$ for November and $0.84 \pm 0.13$ for June were recorded.

Analysis by t test showed no significant difference for the means of GSI and HSI for females at $(P>0.05)$, for males there was significant difference $(\mathrm{t}=6.348$, $P>0.01)$. The results of correlation between tested variables are given on table 2 .

Table 2: Correlation between GSI, HSI, and Rainfall.

\begin{tabular}{|l|l|l|}
\hline$=$ & Males & $0.586^{\star}$ \\
\hline GSI vs HSI & & \\
\hline & Females & -1.574 \\
\hline & Males & -0.362 \\
\hline GSI vs Rainfall & & \\
\hline & Females & -0.448 \\
\hline & Males & -0.303 \\
\hline HIS vs Rainfall & & \\
\hline & Females & -0.014 \\
\hline
\end{tabular}

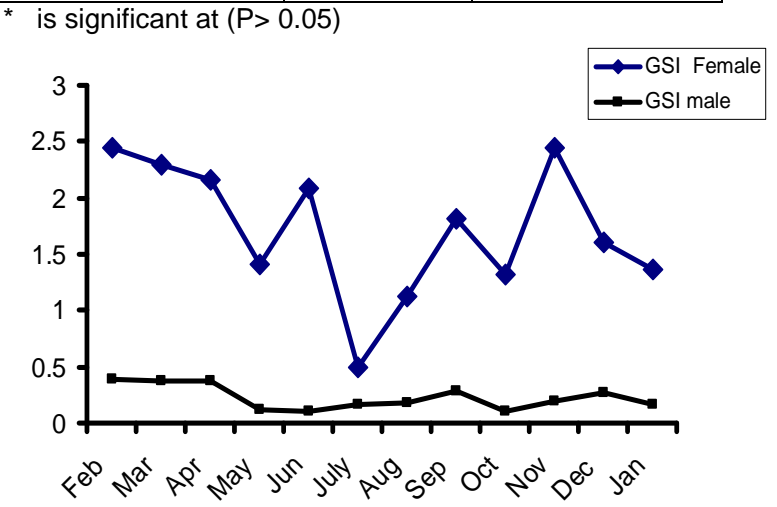

Fig 1a: Gonadosomatic index for male and female $P$ barbarus

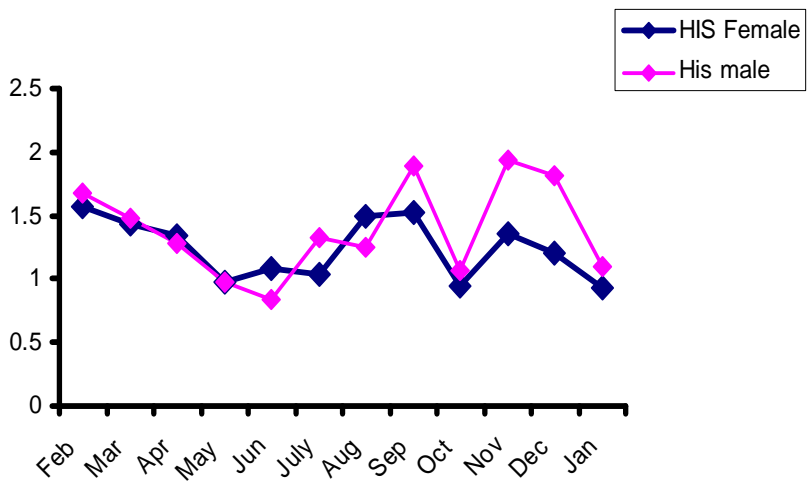

Fig 1b: Hepatosomatic index for male and female $P$ barbarus

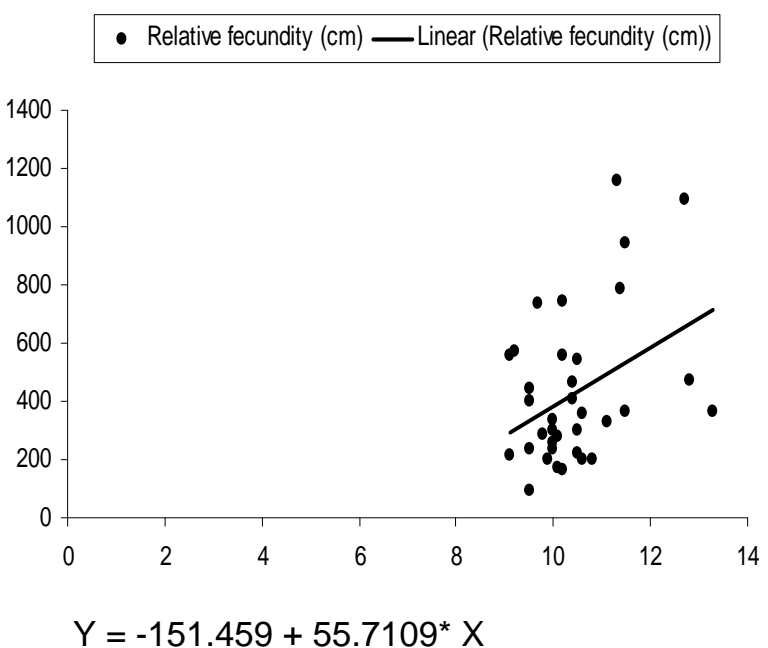

Fig 2: Relative fecundity of $P$ barbarus per $\mathrm{cm}$

\section{DISCUSSION}

The absolute fecundity of the species is on the high side according to the classification by Froese et al (2005). This depicts a species with high resilience to depletion due to heavy exploitation. The relative fecundity showed an increasing trend with length, this could imply increased egg carrying capacity of females with age and size.

The hepatosomatic index (HSI) which is an intrinsic factor for determining stored up energy is affected not only by food availability but also in a population by its composition as matured populations have higher values of HSI, (Katarzyna and Sapota 2005). Closely linked with reproduction and phenology of storage is annual variations in liver mass which could reflect the process of storage and transfer of energy from periods of intensive feeding to periods of restricted feeding but high energy demands (Miller, 1979). The HSI showed a gradual decrease from April to July in both sexes, this could be traced largely to breeding activities. The fall in gonadosomatic index (GSI) at about the same period confirms this assertion. The GSI for males fell drastically between April and May, and February to July for females with a faster fall between April and July. Similar studies by

Etim et al(2002) in Imo River Estuary reported a breeding season running from February to May for males and March to May for females. All measured environmental parameters did not show any effect on the breeding of the species or on the associated factors such as GSI and HSI.

The observed dominance of males during the breeding season is in contrast to the prevalence of 
females observed with Gobius vittatus (Silva and Gordo, 1997). During the spawning period, the decrease in the availability of males is probably due to non availability of the males. Indeed, during the spawning period males of most gobiid species guard nests, so they are hardly caught at all. The predominately female sex ratio of Gobius vittatus during the spawning season, could have resulted from the cryptobenthic behaviour of males. This was also found in Gobius niger (Nash, 1984; Silva and Gordo, 1997). However, Silva and Gordo (1997) noted a significant dominance of males for Gobius niger. Hence, data which do not refer to the spawning period provide a more realistic evaluation of sex ratio in populations of most gobiid species featuring nest guarding behaviour.

\section{REFERENCES}

Adebisi, A.A. (1987). The relationships between fecudities, gonadosomatic indices and egg sizes of some fishes of Ogun River, Nigeria. Archiv Fuer Hydrobiologie, III: 151 - 156.

Brillet, C. (1970). Relations entire territoiret Compartment afresivite chez les Periophthalmes. C.R. Aead. Sci. Poris Serv. D. 270: 1507-1510.

Etim L, King P. R, Udo T. M (2002) Breeding, growth, mortality and yield of the mudskipper Periophthalmus barbarus (Linneaus 1766) (Teleostei Gobiidae) in the Imo River Estuary. Nig. Fis. Res.56(3):277-238.

Ezenwaji, H.M.G and F.N Offiah. (2003). The biology of Pellonula Leomensis Bonlenger, 1916 (Osteichthyes: Clupeidae) in Anambra River, Nigeria. $\mathrm{J}$ of Bio. Res and Biotech. 1 (2): 33-50.
Froese, R. and C. Binohlam. (2000). Empirical relationships to estimate asymptotic length, length at first maturity and length at maximum yield per recruit in fishes, with a simple method to evaluate length frequency data. $J$. Fish Biol. 56; 758 - 773

Froese R, M. Lourdes, D. Palomares and D. Pauly (2005) Estimate of life- history key facts. Available at www.fishbase.com as at November $30^{\text {th }} 2009$.

Inyang, N.M and H.M.G Ezewaji. (2004). Size lengthweight relationships, reproduction and trophic biology of chrysichthys nigrodigitatus and chrysichthys auratus (Siluriformes Bogridae) in a natureal West African lake. J. Bio. Res and Biotech, 2 (1): 47-58.

Katarzyna, W.B and M Sapota (2005) Breeding characteristics of the sand goby (Pomatoschistus minutus) one of the most abundant goby species in the coastal waters of the Gulf of Gdansk Region (Southern Baltic Sea). Oceanological and Hydrobiological Studies 34:4.

Mcgregor, G.(1999). Mudskippers: like fish out of water.? School of life Science (Biology) Queensland University of Technology.

Nash, R.D.M. - 1984. Aspects of the biology of the black goby, Gobius niger L., in Oslofjorden, Norway. Sarsia, 69: 55-61.

Silva, M.N and Gordo, L.S (1997) Age, growth and reproduction of the black goby, Gobius niger, from Obidos Lagoon, Portugal. Cah Biol Mar 38: 175-180.

Vinicius, R.L., M.A. Azevedo., C.B. Fialho. (2004). Reproductive biology of Bryconamericus iheringii (Ostariophysi: characidae) form rio vacacai, Rs, Brazil, Neotrop. Ichthyol. Vol. 2 no 4 porto alegre. 